\title{
Preliminary Acute Oral Toxicity Study of White Tea Leaf (Camellia sinensis (L.) Kuntze) Ethanolic Extracts
}

\author{
Lia Ardiana, Meiliza Ekayanti, Sarah Zielda Najib, Rani Sauriasari, Berna Elya
}

\section{Lia Ardiana, Meiliza Ekay- anti, Sarah Zielda Najib, Rani Sauriasari*, Berna Elya}

Faculty of Pharmacy, University of Indonesia, 16424, Depok, INDONESIA

\section{Correspondence}

\section{Rani Sauriasari,}

Faculty of Pharmacy, University of Indonesia, 16424, Depok, INDONESIA.

Tel: +62 21-727-0031; +62 821-14252811

E-mail: rani@farmasi.ui.ac.id

\section{History}

- Submission Date: 16-01-2017;

- Review completed: 02-03-2017;

- Accepted Date: 27-03-2017

\section{DOI : 10.5530/pj.2017.4.77}

Article Available online

http://www.phcogj.com/v9/i4

\section{Copyright}

(C) 2017 Phcog.Net. This is an openaccess article distributed under the terms of the Creative Commons Attribution 4.0 International license.

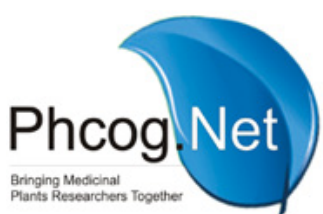

\begin{abstract}
Background: White tea is a kind of tea which manufactured with minimal processing only drying without fermentation process. White tea prepared from very young tea leaves or buds of Camellia sinensis (L.) Kuntze, Theaceae, covered with tiny, silvery hairs, and dried immediately after picking to prevent oxidation and commonly used as a beverage and herbal medicine. Objective: The present study was aimed to evaluate the safety of the white tea leaf ethanolic extract (WTE) with acute toxicity tests. Methods: The acute oral toxicity of WTE performed at dose 1250, 2500, and $5000 \mathrm{mg} / \mathrm{Kg} \mathrm{BW}$ of Deutschland, Denken, and Yoken (DDY) mice. The animals observation for any mortality, behavioral, body weight and feed-water consumption pattern during the 14day study. The liver, kidney, and heart isolation performed on day-15 to observe macroscopic and relative organ weight (ROW). Results: No treatment-related toxic symptom or mortality observed for the first 4 hours and 24 hours after oral administration of WTE at a dose of 1250,2500 , and $5000 \mathrm{mg} / \mathrm{kg} \mathrm{BW}$. All the groups of mice did not show the significant changes in behavior, breathing, and motoric activity. Conclusions: This studies showed that the oral $\mathrm{LD}_{50}$ of WTE was greater than $5000 \mathrm{mg} / \mathrm{kg} \mathrm{BW}$ and suggests that the WTE is practically non-toxic in a single dose of level $5000 \mathrm{mg} / \mathrm{kg}$ BW.

Key words: Acute Toxicity, Camellia Sinensis (L.) Kuntze, Safety, Teh Putih, Theaceae.
\end{abstract}

\section{INTRODUCTION}

The tradition of drinking tea at this time has become one of culture in every community. Therefore, tea is the most popular beverage in the world ${ }^{1}$, made from the leaves of the tea plant, Camellia sinensis (L.) Kuntze, Theaceae. One type of the tea is a white tea that manufactured with minimal processing only drying without fermentation process. White tea leaf, also known as 'teh putih' in Indonesia, prepared from very young tea leaves or buds covered with tiny, silvery hairs, then dried soon after collected, to prevent oxidation. ${ }^{1,2}$ The high concentrations of tea polyphenols and catechins are higher in white tea compared to green or black tea. ${ }^{2}$ The recent investigation associated with the bioactive compound like polyphenols-flavonoids-catechins of tea due to their antioxidant activities which contribute to human health benefits. ${ }^{3,4}$ Pharmacological research indicates that tea leaf extract has pharmacological activities such as antidiabetic, anticarcinogenic, antiviral, antibacterial, antiinflammatory, anti-aging and immune boosting antioxidant activities which contribute to human health. ${ }^{1,-7}$ This activity associated with the efficacy of tea for the prevention and treatment of diasease. $^{8}$

As the second biggest biodiversity in the world, Indonesia has a high number of indigenous medicinal plants. ${ }^{9}$ Therefore, traditional medicine is one of the cultural heritage of ancestors and very well known in Indonesia. Although traditional medicine has been used for a long time but not completely safe, it is important to determine the potential acute toxicity of herbal medicines through $\mathrm{LD}_{50}$ value and the spectrum of toxic effects. The potential acute toxicity of herbal medicine can be used to assess the limits of safety or therapeutic index $\left(\mathrm{LD}_{50} / \mathrm{ED}_{50}\right)$.

The efficacy and toxicity of tea leave assumed from their very long history of consumption in the world and their main functional ingredients studies, ${ }^{7}$ but a systematic evaluation of the toxicity of white tea has been lacking. Therefore, the present study was aimed to evaluate the safety of the white tea leaf ethanolic extract (WTE) with acute toxicity tests in Deutschland, Denken, and Yoken (DDY) mice.

\section{MATERIALS AND METHODS}

\section{Plant Material and Extraction}

The white tea obtained from the Tea Plantation and Quinine Research Center in Gamboeng, West Java, Indonesia. White tea leaves (Camellia sinensis L. Kuntze) sorted and collected then dried under sunlight. Furthermore, the tea leaves withered with a dryer. The white tea leaves powder made by grinding dried white tea leaves by using a grinder. Extraction method conducted by reflux with ethanol $70 \%$ at $60^{\circ} \mathrm{C}$ for 3 hours, then re-reflux for two times and evaporated using evaporator.

\section{Animal Test}

Adult healthy Deutschland, Denken, and Yoken (DDY) mice, weight 20-30 g and approximately six 
weeks old, were used from Department of Pharmacology, University of Indonesia. All mice were acclimatized for seven days before the tests, then fasted four hours before administration of the WTE, while drinking still given.

\section{Acute Toxicity Study}

The oral acute toxicity study of WTE has conducted according to Organization for Economic Co-operation and Development (OECD) guideline with the limit test dose at $5000 \mathrm{mg} / \mathrm{kg}$ body weight (BW).$^{10}$

The animals divided randomly into four groups; each consisted of 10 mice (five males and five females). The $1^{\text {st }}$ group served as a control, while $2^{\text {nd }}$, $3^{\text {rd }}$, and $4^{\text {th }}$ served as treated groups received orally WTE (dissolved in water) with a successive dose of 1250,2500 , and $5000 \mathrm{mg} / \mathrm{kg}$ BW. The WTE was administered only once (on day 0 ) at the beginning of the experiment.

The incidence of toxic effects in animals observed from the first four hours after the treatment period. The change of behavior, body weight, food intake, water intake, motoric activity, respiration and other death observed for 14 days. In the case of the mortality of the animals immediately dissected to see the possible causes. On the $15^{\text {th }}$ day, all of the animals were sacrificed by an anesthesia (ether) after an overnight fasting. The liver, kidney, and heart were isolated and weighed. The relative organ weight (ROW) determined to diagnose injuries that occur in organs during treatment and calculated as follows. ${ }^{11}$

\section{Statistical Analysis}

Statistical analysis determined as mean value \pm standard deviation (SD). The data with normal distribution analyzed with one-way ANOVA followed by multiple comparisons using Bonferroni test. However, abnormal distribution analyzed with Kruskal-Wallis test. Probability level of less than $5 \%(\mathrm{p}<0.05)$ was considered significant.

\section{RESULTS}

No treatment-related toxic symptom or mortality observed for the first $4 \mathrm{~h}$ and $24 \mathrm{~h}$ after oral administration of WTE at a dose of 1250, 2500, and $5000 \mathrm{mg} / \mathrm{kg} \mathrm{BW}$. All the groups of mice did not show the significant changes in behavior, breathing, and motoric activity.

However, the mortality found at day-1, more over 24 hours after administration of WTE, one male mice from the Group 1 and two female mice from the Group 2, but not in Group 3. The animals then immediately dissected to see the cause of the death by obvious observation of liver, kidney, and heart. There were no differences in relative organs weight and apparent observation of their vital organ compare to all of the mice which still alive until the end of observation. The absolute and relative organ masses of all treatment groups showed no significant differences $(\mathrm{P}>0.05)$ compared to control group, (Table 1, 2, 3, and 4). There were no significant differences on obvious observation of vital organs between treatment and control groups, and the appearance seems normal texture (Figure 1 and 2).

Table 1: Average absolute organ weight of male mice

\begin{tabular}{ccccc}
\hline \multirow{2}{*}{ Organ } & \multicolumn{4}{c}{ Average weight* } \\
\cline { 2 - 5 } & Control & Group 1 & Group 2 & Group 3 \\
\hline Liver & $2.10+0.85$ & $2.00+0.08$ & $2.08+0.81$ & $1.90+0.49$ \\
Kidney & $0.22+0.03$ & $0.22+0.03$ & $0.23+0.08$ & $0.19+0.02$ \\
Heart & $0.17+0.06$ & $0.17+0.05$ & $0.14+0.05$ & $0.12+0.04$ \\
Average body on the sacrifice day & $36.07+3.83$ & $32.25+3.52$ & $27.64+4.06$ & $25.24+4.27$ \\
\hline
\end{tabular}

${ }^{*} P>0.05$ compared to control group

Table 2: Average absolute organ weight of female mice

\begin{tabular}{ccccc}
\hline \multirow{2}{*}{ Organ } & \multicolumn{4}{c}{ Average weight* } \\
\cline { 2 - 5 } & Control & Group 1 & Group 2 & Group 3 \\
\hline Liver & $2.2+0.44$ & $1.92+0.43$ & $1.63+0.38$ & $2.2+0.44$ \\
Kidney & $0.23+0.06$ & $0.2+0.04$ & $0.2+0.05$ & $0.23+0.06$ \\
Heart & $0.13+0.06$ & $0.16+0.05$ & $0.13+0.06$ & $0.13+0.06$ \\
Average body on the sacrifice day & $26.67+3.35$ & $25.04+2.83$ & $23.87+3.79$ & $23.48+3.34$ \\
\hline
\end{tabular}

${ }^{*} P>0.05$ compared to control group

Table 3: Relative organ weight of male mice

\begin{tabular}{ccccc}
\hline \multirow{2}{*}{ Organ } & \multicolumn{4}{c}{ Relative organ weight* } \\
& Control & Group 1 & Group 2 & Group 3 \\
\hline Liver & $6.00+3.07$ & $5.98+0.79$ & $7.68+3.37$ & $7.43+0.99$ \\
Kidney & $0.61+0.15$ & $0.72+0.08$ & $0.81+0.18$ & $0.76+0.05$ \\
Heart & $0.45+0.12$ & $0.60+0.21$ & $0.49+0.12$ & $0.48+0.15$ \\
\hline
\end{tabular}

${ }^{\star} P>0.05$ compared to control group
Table 4: Relative organ weight of male mice

\begin{tabular}{ccccc}
\hline \multirow{2}{*}{ Organ } & \multicolumn{4}{c}{ Relative organ weight* } \\
\cline { 2 - 5 } & Control & Group 1 & Group 2 & Group 3 \\
\hline Liver & $2.2+0.43$ & $1.92+0.43$ & $1.63+0.38$ & $1.70+0.28$ \\
Kidney & $0.23+0.06$ & $0.2+0.04$ & $0.20+0.05$ & $0.16+0.05$ \\
Heart & $0.13+0.06$ & $0.16+0.05$ & $0.13+0.06$ & $0.10+0.00$ \\
\hline
\end{tabular}

${ }^{*} P>0.05$ compared to control group 

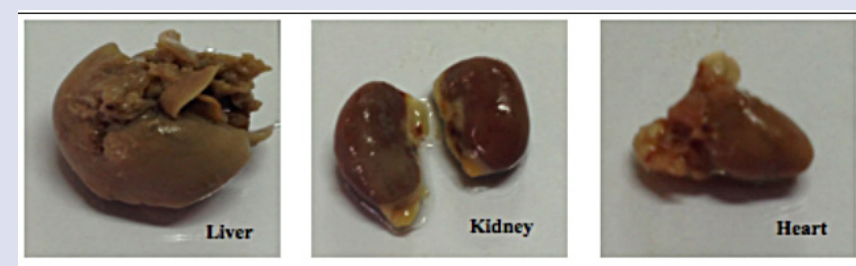

(A)
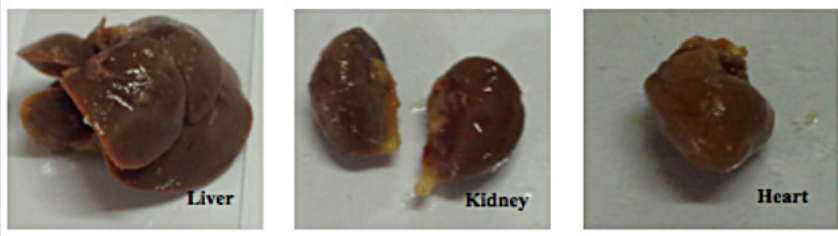

(B)

Figure 1 : Apparence of vital a Oran of male mice, (A) control, (B) group 3 (WTE $5000 \mathrm{mg} / \mathrm{kg} \mathrm{BW}$ ).

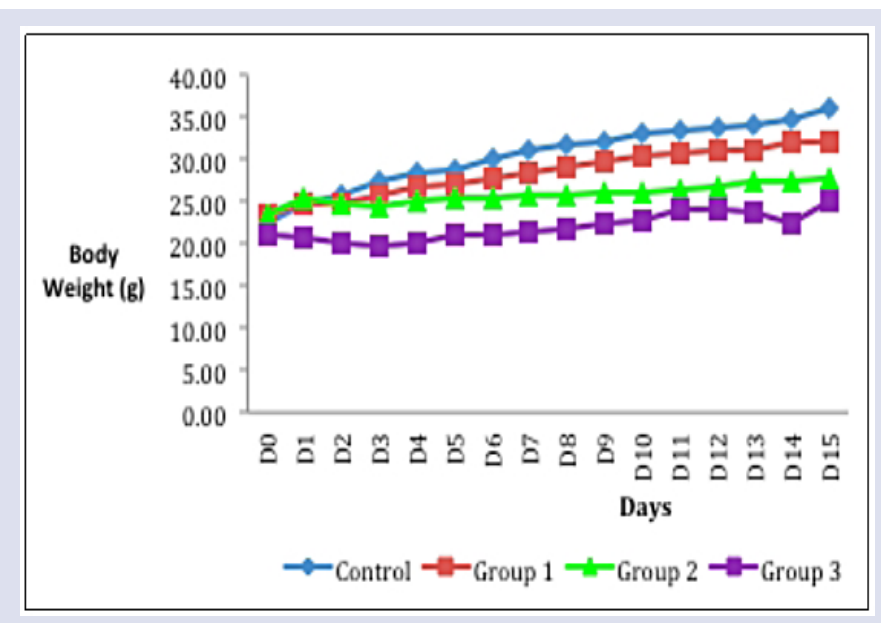

Figure 3: Mean body weight of the male mice.

\section{DISCUSSION}

Observation showed that there was no difference regarding of behavior during the treatment. Decreases or increases in mice body weight found in all of the group treatment and the relative organ masses showed that there were no injuries occur during the treatment. This condition caused by the presence of physiological adaptation response to the extract, especially the effects of the chemical content that causes a decrease in appetite and calorie intake of animal. ${ }^{12}$ The food intake and water consumption all of the group were regular and consistent throughout the study. It is indicating no toxic effect in both controls and treated group.

At the end of studies, day-14 of observations, all animals are live in the group of $5000 \mathrm{mg} / \mathrm{kg}$ body weight as the highest dose and the other group on these study. Based on this observation, WTE seems to be safe at a dose level of $5000 \mathrm{mg} / \mathrm{kg} \mathrm{BW}$, and the $\mathrm{LD}_{50}$ is considered be $>5000$ $\mathrm{mg} / \mathrm{kg}$ BW. Although the safety data of WTE also support by the traditional uses of tea leaves as a beverage which have long history consumption in the world, this study provides data on the acute toxicity profile of WTE that should be very useful for any future in vivo and clinical study of this plant.

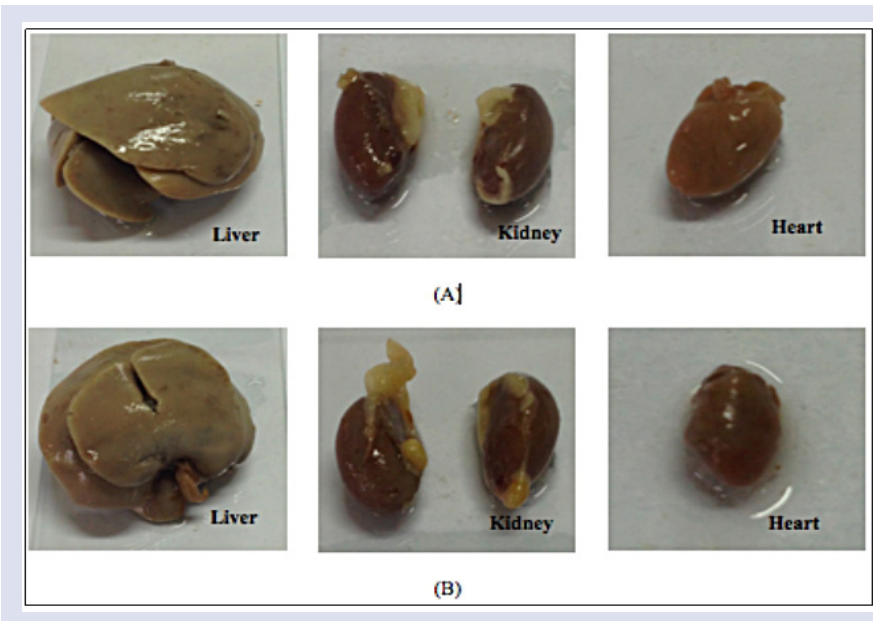

Figure 2 : Apparence of a vital origan of female mice, (A) control, (B) group 3 (WTE $5000 \mathrm{mg} / \mathrm{kg} \mathrm{BW).}$

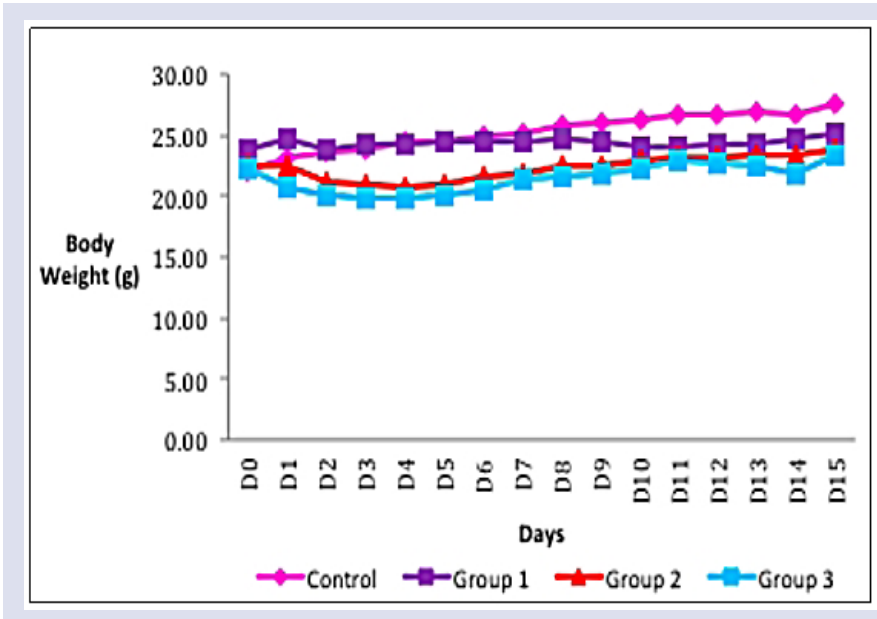

Figure 4 : Mean body weight of the female mice.

\section{CONCLUSION}

In conclusion, this studies showed that the oral $\mathrm{LD}_{50}$ of WTE was greater than $5000 \mathrm{mg} / \mathrm{kg} \mathrm{BW}$ and suggests that the WTE is found to be safe in a single dose of level $5000 \mathrm{mg} / \mathrm{kg}$ BW. However, the safety of long-term uses of white tea leaves especially in the treatment of the chronic disease should be confirmed with sub- acute toxicity study.

\section{ACKNOWLEDGMENT}

This work supported by PITTA Grant University of Indonesia. The authors thank all their colleagues for their great prestigious encouragement in accomplishing this task.

\section{CONFLICT OF INTEREST}

The authors have no conflict of interest to declare.

\section{ABBREVIATION USED}

WTE: White tea leaf ethanolic extract; DDY: Deutschland, Denken and Yoken; BW: Body weight; OECD: Organization for Economic Co-opera- 
tion and Development; ROW: Relative organ weight; $\mathrm{LD}_{50}$ : Lethal doses; $\mathrm{ED}_{50}$ : Effective dose; SD: Standard deviation.

\section{REFERENCES}

1. Tadesse A, Hymete A, Bekhit AA, Mohammed SF. Quantification of total polyphenols, catechin, caffeine, L-theanine, determination of antioxidant activity and effect on antileishmanial drugs of Ethiopian tea leaves extracts. Phcog Res $2015 ; 7: 7-14$

2. Hilal $Y$, Engelhardt U. Characterization of white tea-comparison to green and black tea. J. Vergbr. Lebensm. 2007;2:414-21.

3. Boros K, Jedlinszki N, Csupor D. Theanine and Caffeine content of infusions prepared from commercial tea samples. Phcog Mag 2016;12:75-9.

4. Goenka P, Sarawgi A, Karun V, Nigam AG, Dutta S, Marwah N. Camellia sinensis (Tea): Implications and role in preventing dental decay. Phcog Rev 2013;7:152-6.

5. Elya B, Handayani R, Sauriasari R, Hassyati US, Permana IT, Permatasari YI. Activity antidiabetic and phytochemical screening of extract from Indonesian plants by inhibition of alpha-glucosidase and dipeptidyl peptidases IV. Pakistan Journal of Biological Science. 2015;18:279-84.

6. Thring TS, Hili P, Naughton DP. An antioxidant and potential anti-inflammatory activity of extracts and formulations of white tea, rose, and witch hazel on primary human dermal fibroblast cells. J Inflamm (Lond). 2011;8:27.

7. Li B, Jin Y, Xu Y, Wu Y, Xu J, Tu, Y. Safety Evaluation of Tea (Camellia sinensis (L.) O. Kuntze) Flower Extract: Assessment of Mutagenicity, and Acute and Subchronic Toxicity in Rats. Journal of Ethnopharmacology. 2011:133:583-90.

8. Elfahmi, Woerdenbag HJ, Kayse O. Jamu: Indonesian Traditional Herbal Medicine Towards Rational Phytopharmacological Use: Review. Journal of Herbal Medicine. 2014;4:51-73.

9. Aladag H, Ercisli S, Yesil DZ, Gormez A, Yesil M. Antifungal activity of green tea leaves (Camellia sinensis L.) sampled in different harvest time. Phcog Mag 2009:5:437-40

10. Organization for Economic Co-operation and Development. OECD guidelines for the testing of chemicals: Acute Oral Toxicity No. 401. OECD. 1987.

11. Rajeh MB, Kwan YP, Zakaria Z, Latha LY, Jothy SL, Sasidharan S. Acute toxicity impacts of Euphorbia hirta $L$ extract on behavior, organs body weight index and histopathology of organs of the mice and Artemia salina. Phcog Res 2012;4:170-7.

12. Arsad SS, Esa NM, Hamzah H, Othman F. Evaluation of Acute, Subacute and Subchronic Oral Toxicity of Rhaphidophora decursiva (Roxb.) Schott Extract in Male Sprague Dawley Rats. Journal of Medicinal Plants Research. 2013:7:3030-40.

\section{GRAPHICAL ABSTRACT}

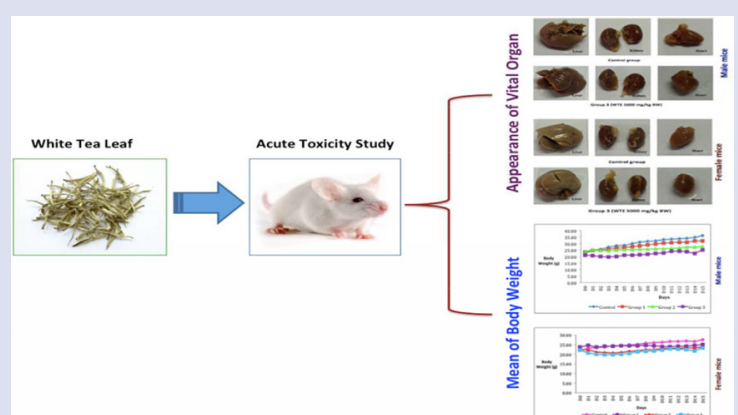

\section{SUMMARY}

- No treatment-related toxic symptom or mortality observed for the first 4 hours and 24 hours after oral administration of white tea leaf ethanolic extract in mice upto a dose of $5000 \mathrm{mg} / \mathrm{kg} \mathrm{BW}$.

- Both male and female treated mice showed no significant changes in behavior, breathing, and motoric activity.

- The oral LD50 of white tea leaf ethanolic extract was greater than $5000 \mathrm{mg} /$ $\mathrm{kg} \mathrm{BW}$ and suggests practically non-toxic in a single dose of level $5000 \mathrm{mg} /$ kg BW.

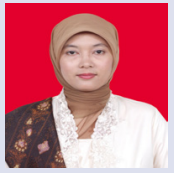

\section{ABOUT AUTHORS}

Lia Ardiana: She is a magister student at the Faculty of Pharmacy, University of Indonesia. Her magister research focused on the evaluation of toxicity and antidiabetic activity of Indonesian herbal medicines.

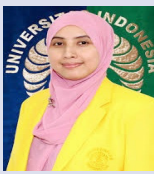

Rani Sauriasari: working as lecturer and researcher in Faculty of Pharmacy, University of Indonesia. Her doctor degree obtained from Public Health (Medical Faculty), Okayama University, Japan. Currently, she is positioned as Manager of Research and Community Engagement, Faculty of Pharmacy, University of Indonesia. Has experience in the area of Biochemistry, Analitycal Chemistry and Pharmacology, working mainly in: medicinal plants and new research drugs.

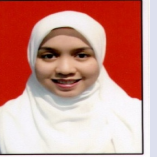

Meiliza Ekayanti: She is a researcher that focused on Phytochemistry at the Faculty of Pharmacy, University of Indonesia.

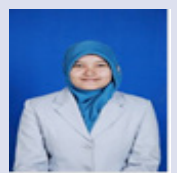

Sarah Zielda Najib: She is a researcher of medicinal plants activity at the Faculty of Pharmacy, University of Indonesia.

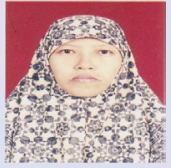

Berna Elya: She is Professor and researcher with the mainly area in isolation of new compound from medicinal plants, Pharmacognosy and Phytochemistry. Currently, she is positioned as lecturer and Head of Laboratory of Pharmacognosy, Faculty of Pharmacy, University of Indonesia.

Cite this article: Ardiana L, Ekayanti M, Najib SZ, Sauriasari R, Elya B. Preliminary Acute Oral Toxicity Study of White Tea Leaf (Camellia sinensis (L.) Kuntze) Ethanolic Extracts. Pharmacogn J. 2017;9(4):479-82. 